\title{
An investigation of NOS2A promoter polymorphisms in Australian multiple sclerosis patients
}

\author{
Matthew J Bugeja ${ }^{1}$, David R Booth ${ }^{1}$, Bruce H Bennetts ${ }^{2,3}$, Robert NS Heard ${ }^{1}$, David Burgner ${ }^{4}$ \\ and Graeme J Stewart*,1
}

\begin{abstract}
${ }^{1}$ The Institute for Immunology and Allergy Research, Westmead Millennium Institute, Westmead Campus, University of Sydney, Westmead NSW 2145, Australia; ${ }^{2}$ Department of Molecular Genetics, The Children's Hospital at Westmead, University of Sydney, Westmead NSW 2145, Australia; ${ }^{3}$ School of Paediatrics and Child Health, University of Sydney, NSW 2006, Australia; ${ }^{4}$ School of Paediatrics and Child Health, University of Western Australia, Perth, WA 6840, Australia
\end{abstract}

As with other major autoimmune diseases, susceptibility to multiple sclerosis (MS) is believed to result from the complex interaction of a number of genes, each with modest effect. Extensive research of experimental autoimmune encephalomyelitis in mice and several direct MS studies have implicated NOS2A, which encodes the inducible form of nitric oxide synthase, and the genetic region encoding NOS $2 A, 17 q 11.2$, has been identified in a number of genome wide screens as being potentially associated with MS. We investigated four single nucleotide polymorphisms in the proximal promoter region of NOS $2 A$, in a case-control group of 100 Australian MS patients and 100 controls and in 203 MS patients and their unaffected parents. We found a trend toward excess transmission of the $-277 \mathrm{~A}$ allele (tag for the AGCC haplotype) to HLA-DRB 1*1501-positive MS patients $(P$ (uncorrected) $=0.05)$. We initially discovered a trend toward over-representation of the AGCC haplotype in HLA-DRB1*1501-positive compared to HLA-DRB1*1501-negative MS patients in the case-control cohort. However, when combined with the probands from the transmission disequilibrium analysis, this trend was nullified. Nonetheless, despite the lack of significant evidence of association for the NOS2A promoter polymorphisms with MS, the gene remains an interesting candidate for MS susceptibility, particularly with regard to the HLA-DRB1*1501 haplotype.

European Journal of Human Genetics (2005) 13, 815-822. doi:10.1038/sj.ejhg.5201422

Published online 27 April 2005

Keywords: inducible nitric oxide synthase; multiple sclerosis; promoter polymorphism

Introduction

Multiple sclerosis (MS) is believed to be an autoimmune disease resulting in inflammation of the central nervous system (CNS), demyelination and destruction of neural supporting cells. ${ }^{1}$ However, the mechanisms underlying this pathology are still poorly understood. A multifactorial aetiology for MS has been suggested by epidemiological

*Correspondence: Dr G Stewart, Institute for Immunology and Allergy Research, Level 2, ICPMR, Westmead Hospital, Westmead, NSW, 2145, Australia. Tel: +6129845 6791; Fax: + 6129891 3889;

E-mail: stewartg@westgate.wh.usyd.edu.au

Received 18 August 2004; revised 3 March 2005; accepted 9 March 2005 studies, implicating a complex interplay between genetic and environmental factors. An important role for genetic heritability in MS is suggested by the results of twin, halfsib and adoptee studies., ${ }^{2,3}$ The only robust genetic association that has been found is with the HLADRB1*1501, DQA1*0102, DQB1*0602 haplotype in Caucasian populations. ${ }^{4,5}$ A large number of genome wide screens have been conducted in recent years; most recently the GAMES collaboration (Genetic Analysis of Multiple sclerosis in EuropeanS), which pooled the collective resources of 16 European countries and Australia (migrant European), in screens for linkage disequilibrium (LD). ${ }^{6}$ While no region consistently reached the level of significance 
attained for the HLA region, multiple regions showed potential association at a level of probability greater than that expected by chance alone. These results reinforce the concept that many genetic factors of modest contribution are likely to combine in predisposing individuals to MS, which, if identified, may present important targets for new therapies. $^{7}$

Nitric oxide (NO) has been widely implicated as playing a role in the pathogenesis of MS. NO has an immense diversity of immunological functions, ${ }^{8}$ including the destruction of target cells and immunosuppression. NO is synthesised by nitric oxide synthase (NOS), which exists in three isoforms: endothelial (eNOS) and neuronal (nNOS), which are constitutively expressed, and inducible (iNOS), which is induced by several proinflammatory cytokines, including interferon (IFN)- $\gamma$, IFN- $\alpha$ and interleukin (IL)-1 $\beta .^{9}$ iNOS expression and NO metabolites have been found to be elevated in brain tissue and cerebrospinal fluid of MS patients compared to controls. ${ }^{10-12}$ Studies into the role of iNOS in MS pathogenesis in the rodent model of MS, experimental autoimmune encephalomyelitis (EAE), have produced conflicting data suggesting either a protective role for NO or a destructive role (reviewed in Willenborg et $a l^{13}$ ).

The gene encoding iNOS, NOS $2 A$, is located on chromosome $17 \mathrm{q} 11.2$, a region consistently identified in genome wide screens as suggestive for linkage and association with MS, ${ }^{14-19}$ and the NOS2A locus was specifically identified in a multilocus single nucleotide polymorphism (SNP) assay as being of strong linkage and association in MS. ${ }^{20}$ NOS $2 A$ is a predominantly transcriptionally regulated gene ${ }^{21-24}$ and promoter variants have been associated with various diseases, including complications in type II diabetes, ${ }^{25}$ outcome of hepatitis $\mathrm{C}$ virus infection, ${ }^{26}$ cerebral malaria $^{27,28}$ and dementia. ${ }^{29}$

Two independent studies have analysed a pentanucleotide repeat in the promoter region for association with MS. ${ }^{30,31}$ Neither study found evidence for an association between the repeat and MS in relatively small cohorts. However, this microsatellite was unsuitable for association analysis as recent data suggested that LD has largely broken down between this NOS $2 A$ microsatellite and four recently described nearby common SNPs in the NOS $2 A$ promoter. ${ }^{27,32}$ Hence, we undertook the first analysis of association with MS susceptibility for these SNPs. We analysed individual SNPs and haplotypes in a cohort of MS cases and controls, and then analysed one of the SNPs as a haplotype tag in a cohort of trios (affected patient and unaffected parents) for transmission disequilibrium.

\section{Materials and methods Subjects}

For the case-control study, we analysed 100 patients with MS and 100 unrelated controls, composed largely of local staff members and the spouses of MS patients. For the transmission disequilibrium study, we analysed 203 randomly selected MS patients and their unaffected parents (trios). Approximately $90 \%$ of patients and controls were of Northern European origin, while the remainder were largely of Southern European origin. Diagnosis was overseen by a neurologist (RNSH); all patients had MS as defined by the Poser criteria, ${ }^{33}$ provided written, informed consent, and were recruited by our facility: the Institute for Immunology and Allergy Research, Westmead Hospital (Australia).

\section{Genotyping}

Case-control study Samples were genotyped by partially denaturing high-performance liquid chromatography (dHPLC) using the WAVE DNA Fragment Analysis System (Transgenomic). Details of primer combinations and dHPLC conditions for the genotyping of each SNP are listed in Table 1. After PCR amplification by a standard touchdown PCR method, $10 \mu \mathrm{l}$ of each sample was denatured by heating to $95^{\circ} \mathrm{C}$ for $10 \mathrm{~min}$, then cooling to $50^{\circ} \mathrm{C}$ at a rate of $1^{\circ} \mathrm{C} / \mathrm{min}$ to maximise heteroduplex formation. Samples were then analysed by $\mathrm{dHPLC}^{34}$ at the melting temperatures as defined in Table 1, which were determined using the Wavemaker software package (Transgenomic, Crewe, UK). Those samples initially genotyped as homozygous were repeated after mixing of $5 \mu \mathrm{l}$ of sample with $5 \mu \mathrm{l}$ of a known homozygous control, which was confirmed by DNA sequencing. This could then be used to determine whether homozygotes were of a wild type or variant genotype.

All PCR reactions were set up with $0.5 \mathrm{U}$ Amplitaq Gold, $1 \times$ Buffer II and $2 \mathrm{mM} \mathrm{MgCl}_{2}$ (Applied Biosystems, Foster City, USA), plus $0.2 \mathrm{~mm}$ each dNTP (Promega), $5 \mathrm{ng} / \mu \mathrm{l}$ each primer (Sigma Genosys) in a final reaction volume of $20 \mu \mathrm{l}$ in water for irrigation (recommended to minimise damage to the dHPLC column).

Table 1 Primers and dHPLC conditions for genotyping of four NOS2A promoter SNPs (SNP locations are relative to the transcriptional start site; forward primers in upper case, reverse primers in lower case)

\begin{tabular}{|c|c|c|}
\hline SNP & Primers & $d H P L C \operatorname{Tm}\left({ }^{\circ} \mathrm{C}\right)$ \\
\hline$-277 A / G$ & $\begin{array}{l}5^{\prime} \text {-СТТССТТССТТСССТТССА-3' } \\
5^{\prime} \text {-cctctttctggtcccaagtc-3' }\end{array}$ & 61.4 \\
\hline$-1026 \mathrm{G} / \mathrm{T}$ & $\begin{array}{l}5^{\prime} \text {-CATGTCTTTTTTGTGGCTC-3' } \\
5^{\prime} \text {-atgttgtccatgctggtctc- } 3^{\prime}\end{array}$ & 60.8 \\
\hline$-1659 \mathrm{C} / \mathrm{T}$ & $\begin{array}{l}\text { 5'-GTCCTCTCCCTTGTAAACTT-3' } \\
5^{\prime} \text {-caaagecatcttcccttc-3' }\end{array}$ & 57.2 \\
\hline$-2447 C / G$ & $\begin{array}{l}\text { 5'-GAGACAGGCTAGGGTGCAG-3' } \\
5^{\prime} \text {-cggcttagaactctggctta-3' }\end{array}$ & 60.3 \\
\hline
\end{tabular}


Transmission disequilibrium study Samples were genotyped for the $-277 \mathrm{~A} / \mathrm{G}$ SNP using the SNaPshot primerextension technique. ${ }^{35}$ Primers for initial amplification were as for the case-control study. PCR products were prepared for the primer extension assay by incubating $4 \mu \mathrm{l}$ product with $1 \mu \mathrm{l}$ ExoSAPIT (Amersham) for $15 \mathrm{~min}$ at $37^{\circ} \mathrm{C}$, then $15 \mathrm{~min}$ at $80^{\circ} \mathrm{C}$. In all, $2.5 \mu \mathrm{l} \mathrm{SNaPshot} \mathrm{solution}$ (Applied Biosystems), plus $0.1 \mathrm{pmol}$ extension primer was added to the reaction mix. The sequence for the extension primer was 5'-CATGCATGCATGCATGCATCCTGGCTCC GTGGTGCCTCT-3'. The SNaPshot reaction was then run and samples were prepared and analysed according to the manufacturer's instructions (Applied Biosystems).

HLA typing The HLA-DRB1*1501 allele was genotyped by SYBR Green (Applied Biosystems) real-time PCR amplification, as described previously. ${ }^{36}$

\section{Determination of LD and haplotypes}

The HelixTree genetics analysis software (Golden Helix Inc., Bozeman, USA) was used to calculate LD for the four SNPs and to determine haplotypes. By using the expectation/maximisation (EM) algorithm, the software was able to calculate probabilities of each haplotype occurring, based on multilocus genotypes. It calculated $D^{\prime}$ and $r^{2}$ values, which are accepted measures of $\mathrm{LD}$, and performed a $\chi^{2}$ comparison for each pair of SNPs.

\section{Statistical analyses}

$\chi^{2}$ analysis with Yates' correction was used to compare all allele and genotype frequencies obtained in the casecontrol study, including stratified data, and for the combined case-control-transmission disequilibrium test (TDT) proband analysis. Fisher's exact test was used to compare haplotype frequencies. For this analysis, two-bytwo contingency tables were constructed, grouping the haplotypes as AGCC and not AGCC.
Trio data were analysed using the TDT. ${ }^{37}$ Informative families were defined as those where either or both of the parents were heterozygous at the locus. Analysis was performed using the EasyTDT software, available online (www.SequenceAnalysis.com).

\section{Results \\ Population distribution of NOS2A SNP alleles}

NOS $2 A$ promoter polymorphisms are increasingly being implicated in the outcome of a number of diseases. However, little is known of the population genetics of these polymorphisms. Allele and haplotype frequency data in large Caucasian cohorts have been presented in two previous studies. ${ }^{26,32}$ Table 2 shows a comparison of these data with the results of this study. The minor allele frequencies are quite similar between the cohorts, with a marked difference existing only between the Caucasian cohorts and the Gambian cohort. ${ }^{32}$ The distribution of haplotypes was similarly concordant between the Caucasian cohorts (data not shown).

\section{Case-control analysis}

Table 3 shows the allele and genotyping data for the analysis of the $100 \mathrm{MS}$ cases and controls. All sample groups conformed to the Hardy-Weinberg equilibrium. No significant differences in allelic or genotypic frequencies were observed for any of the four NOS2A promoter SNPs when compared in all MS patients and all controls. When stratified for HLA-DRB1*1501 status, there was a trend towards over-representation of the variant (minor allele) homozygous genotype for all four SNPs in HLADRB1*1501-negative MS patients, but this was not significant. There was also a trend towards association for the $-1026 \mathrm{G} / \mathrm{T}$ SNP when compared between HLADRB1*1501-negative MS patients and controls ( $P$ (uncorrected) $=0.05$ )

Table 2 Summary of data for the minor allele frequencies of NOS2A promoter polymorphisms in Caucasian and African populations

\begin{tabular}{|c|c|c|c|c|}
\hline Study & $-277 A / G$ & $-1026 \mathrm{G} / T$ & $-1659 \mathrm{C} / \mathrm{T}$ & $-2447 C / G$ \\
\hline \multicolumn{5}{|l|}{ Current study } \\
\hline Case-control (controls; $n=100$ individuals) (\%) & 34.5 & 26.5 & 11.5 & 36.5 \\
\hline TDT (parents; $n=406$ individuals) (\%) & 40.8 & - & - & - \\
\hline \multicolumn{5}{|l|}{ Burgner et $a l^{32}$} \\
\hline UKK Caucasians ( $n=92$ families) (\%) & 34.3 & 22.7 & 9.7 & 27.8 \\
\hline \multicolumn{5}{|l|}{ Yee et $a 1^{26}$} \\
\hline European Caucasians $\left(n=619\right.$ individuals) ${ }^{\mathrm{a}}(\%)$ & 37.7 & 30.4 & 12.8 & $ـ^{\mathrm{b}}$ \\
\hline \multicolumn{5}{|l|}{ Burgner et $a l^{32}$} \\
\hline Gambian ( $n=109$ families) (\%) & 46 & 46 & 25 & 40 \\
\hline
\end{tabular}


Table 3 Genotype and allele frequencies of the four NOS2A promoter polymorphisms in MS patients and controls and in a combined analysis including probands from the TDT study

\begin{tabular}{|c|c|c|c|c|c|}
\hline \multirow[b]{2}{*}{$\begin{array}{l}-277 \\
\text { All individuals }\end{array}$} & \multicolumn{3}{|c|}{ Genotype frequency } & \multicolumn{2}{|c|}{ Allele frequency } \\
\hline & $A / A$ & $A / G$ & $G / G$ & $A$ & $G$ \\
\hline $\begin{array}{l}\text { MS cases }(n=100) \\
\text { TDT probands }(n=125) \\
\text { Combined }(n=225) \\
\text { Controls }(n=100)\end{array}$ & $\begin{array}{c}41 \\
47(37.6 \%) \\
88(39.1 \%) \\
40\end{array}$ & $\begin{array}{c}46 \\
62(49.6 \%) \\
108(48.0 \%) \\
51\end{array}$ & $\begin{array}{c}13 \\
16(12.8 \%) \\
29(12.9 \%) \\
9\end{array}$ & $\begin{array}{l}128(64.0 \%) \\
156(62.4 \%) \\
284(63.1 \%) \\
131(65.5 \%)\end{array}$ & $\begin{array}{r}72(36.0 \%) \\
94(37.6 \%) \\
166(36.9 \%) \\
69(34.5 \%)\end{array}$ \\
\hline $\begin{array}{l}\text { DRB } 1 * 1501 \text { positive } \\
\text { MS cases }(n=60) \\
\text { TDT probands }(n=74) \\
\text { Combined }(n=134) \\
\text { Controls }(n=29)\end{array}$ & $\begin{array}{l}27(45.0 \%) \\
24(32.4 \%) \\
51(38.1 \%) \\
12(41.4 \%)\end{array}$ & $\begin{array}{l}28(46.7 \%) \\
39(52.7 \%) \\
67(50.0 \%) \\
13(44.8 \%)\end{array}$ & $\begin{aligned} 5 & (8.3 \%) \\
11 & (14.9 \%) \\
16 & (11.9 \%) \\
4 & (13.8 \%)\end{aligned}$ & $\begin{array}{r}82(68.3 \%) \\
87(58.8 \%) \\
169(63.1 \%) \\
37(63.8 \%)\end{array}$ & $\begin{array}{l}38(31.7 \%) \\
61(41.2 \%) \\
99(36.9 \%) \\
21(36.2 \%)\end{array}$ \\
\hline $\begin{array}{l}\text { DRB1*1501 negative } \\
\text { MS cases }(n=39) \\
\text { TDT probands }(n=51) \\
\text { Combined }(n=90) \\
\text { Controls }(n=71)\end{array}$ & $\begin{array}{l}14(35.9 \%) \\
23(45.1 \%) \\
37(41.1 \%) \\
28(39.4 \%)\end{array}$ & $\begin{array}{l}17(43.6 \%) \\
23(45.1 \%) \\
40(44.4 \%) \\
38(53.5 \%)\end{array}$ & $\begin{aligned} 8 & (20.5 \%) \\
5 & (9.8 \%) \\
13 & (14.4 \%) \\
5 & (7.0 \%)\end{aligned}$ & $\begin{array}{r}45(57.7 \%) \\
69(67.6 \%) \\
114(63.3 \%) \\
94(66.2 \%)\end{array}$ & $\begin{array}{l}33(42.3 \%) \\
33(32.4 \%) \\
66(36.7 \%) \\
48(33.8 \%)\end{array}$ \\
\hline $\begin{array}{l}-1026 \\
\text { All individuals } \\
\text { MS } \\
\text { Controls }\end{array}$ & $\begin{array}{l}G / G \\
50 \\
52\end{array}$ & $\begin{array}{l}G / T \\
40 \\
43\end{array}$ & $\begin{array}{c}T / T \\
10 \\
5\end{array}$ & $\begin{array}{c}G \\
140(70.0 \%) \\
147(73.5 \%)\end{array}$ & $\begin{array}{c}T \\
60(30.0 \%) \\
53(26.5 \%)\end{array}$ \\
\hline $\begin{array}{l}\text { DRB1*1501 positive } \\
\text { MS } \\
\text { Controls }\end{array}$ & $\begin{array}{l}33(55.0 \%) \\
18(62.1 \%)\end{array}$ & $\begin{array}{r}24(40.0 \%) \\
9(31.0 \%)\end{array}$ & $\begin{array}{l}3(5.0 \%) \\
2(6.9 \%)\end{array}$ & $\begin{array}{l}90(75.0 \%) \\
45(77.6 \%)\end{array}$ & $\begin{array}{l}30(25.0 \%) \\
13(22.4 \%)\end{array}$ \\
\hline $\begin{array}{l}\text { DRB1*1501 negative } \\
\text { MS } \\
\text { Controls }\end{array}$ & $\begin{array}{l}17(43.6 \%) \\
34(47.9 \%)\end{array}$ & $\begin{array}{l}15(38.5 \%) \\
34(47.9 \%)\end{array}$ & $\begin{array}{l}7(18.0 \%)^{\star} \\
3(4.2 \%)^{\star}\end{array}$ & $\begin{array}{r}49(62.8 \%) \\
102(71.8 \%)\end{array}$ & $\begin{array}{l}29(37.2 \%) \\
40(28.2 \%)\end{array}$ \\
\hline $\begin{array}{l}-1659 \\
\text { All individuals } \\
\text { MS } \\
\text { Controls }\end{array}$ & $\begin{array}{l}C / C \\
75 \\
77\end{array}$ & $\begin{array}{l}C / T \\
23 \\
23\end{array}$ & $\begin{array}{l}T / T \\
2 \\
0\end{array}$ & $\begin{array}{c}C \\
173(86.5 \%) \\
177(88.5 \%)\end{array}$ & $\begin{array}{c}T \\
27(13.5 \%) \\
23(11.5 \%)\end{array}$ \\
\hline $\begin{array}{l}\text { DRB1*1501 positive } \\
\text { MS } \\
\text { Controls }\end{array}$ & $\begin{array}{l}47(78.3 \%) \\
23(79.3 \%)\end{array}$ & $\begin{array}{r}13(21.7 \%) \\
6(20.7 \%)\end{array}$ & $\begin{array}{l}0 \\
0\end{array}$ & $\begin{array}{r}107(89.2 \%) \\
52(89.7 \%)\end{array}$ & $\begin{array}{r}13(10.8 \%) \\
6(10.3 \%)\end{array}$ \\
\hline $\begin{array}{l}\text { DRB1*1501 negative } \\
\text { MS } \\
\text { Controls }\end{array}$ & $\begin{array}{l}28(71.8 \%) \\
54(76.1 \%)\end{array}$ & $\begin{array}{r}9(23.1 \%) \\
17(23.9 \%)\end{array}$ & $\begin{array}{c}2(5.1 \%) \\
0\end{array}$ & $\begin{array}{r}65(83.3 \%) \\
125(88.0 \%)\end{array}$ & $\begin{array}{l}13(16.7 \%) \\
17(12.0 \%)\end{array}$ \\
\hline $\begin{array}{l}-2447 \\
\text { All individuals } \\
\text { MS } \\
\text { Controls }\end{array}$ & $\begin{array}{l}C / C \\
39 \\
37\end{array}$ & $\begin{array}{l}C / G \\
47 \\
53\end{array}$ & $\begin{array}{l}G / G \\
14 \\
10\end{array}$ & $\begin{array}{c}C \\
125(62.5 \%) \\
127(63.5 \%)\end{array}$ & $\begin{array}{c}G \\
75(37.5 \%) \\
73(36.5 \%)\end{array}$ \\
\hline $\begin{array}{l}\text { DRB1*1501 positive } \\
\text { MS } \\
\text { Controls }\end{array}$ & $\begin{array}{l}27(45.0 \%) \\
12(41.4 \%)\end{array}$ & $\begin{array}{l}28(46.7 \%) \\
13(44.8 \%)\end{array}$ & $\begin{array}{l}5(8.3 \%)^{\star *} \\
4(13.8 \%)\end{array}$ & $\begin{array}{l}82(68.3 \%) \\
37(63.8 \%)\end{array}$ & $\begin{array}{l}38(31.7 \%)^{\star * \star} \\
21(36.2 \%)\end{array}$ \\
\hline $\begin{array}{l}\text { DRB } 1{ }^{*} 1501 \text { negative } \\
\text { MS } \\
\text { Controls }\end{array}$ & $\begin{array}{l}12(30.8 \%) \\
25(35.2 \%)\end{array}$ & $\begin{array}{l}18(46.2 \%) \\
40(56.3 \%)\end{array}$ & $\begin{array}{l}9(23.1 \%)^{\star *} \\
6(8.5 \%)\end{array}$ & $\begin{array}{l}42(53.9 \%) \\
90(63.4 \%)\end{array}$ & $\begin{array}{l}36(46.2 \%)^{\star * *} \\
52(36.6 \%)\end{array}$ \\
\hline
\end{tabular}

${ }^{\star} P($ uncorrected $)=0.05,{ }^{* *} P$ (uncorrected $)=0.09,{ }^{* \star *} P$ (uncorrected $)=0.06$.

The haplotype distribution is shown in Table 4. No association was found for the AGCC haplotype when compared in all MS patients and controls. An association, significant before correction for multiple testing, was found for the AGCC haplotype upon stratification for HLA$\mathrm{DRB}^{*} 1501$ status in MS patients $(P$ (uncorrected $\left.)=0.04\right)$. 
While none of the above results were robust to the Bonferroni correction for multiple comparisons, it was not applied to avoid type II error. ${ }^{38}$

All four SNPs were in significant LD as previously demonstrated $^{32}$ (Table 5). It should be noted that owing to the high LD between the four SNPs, allocation of haplotypes for all individuals was achieved with greater than $99 \%$ certainty by the EM algorithm.

\section{Analysis of trio families}

The results of the case-control analysis were highly informative regarding the establishment of allele, genotype and haplotype frequencies, and led us to further explore the NOS2A locus in a larger cohort. Further, since significant LD was observed between all four of the NOS $2 A$ promoter SNPs analysed, the $-277 \mathrm{~A}$ allele was selected as the most informative SNP and as a tag for the AGCC haplotype in the trio families. While the $-277 \mathrm{~A}$ allele also occurred on the uncommon AGCG haplotype, the low frequency of this haplotype (1.5\% of all individuals) conferred only a minor effect on the study; this conclusion is consistent with the proposal by Johnson et al, ${ }^{39}$ who excluded haplotypes of less than 5\% frequency when defining haplotype tagging SNPs. This SNP also occurred with a high minor allele frequency, so that there was improved statistical power to detect a moderate association in the study population. Transmission of the $-277 \mathrm{~A}$ allele was analysed in 203 trio families (Table 6). Probands and parents were in Hardy-Weinberg equilibrium. 150 trios (74\%) were informative. It was found that the A allele was transmitted in excess to a significant level, before correction for multiple testing, amongst all the informative trios (transmission $=57 \%, \quad 95 \% \quad \mathrm{CI}=50-64 \%, \quad P \quad$ (uncorrected $=0.05)$. Upon HLA-DRB1*1501 stratification, this trend for excess transmission of the A allele was maintained only for the HLA-DRB1*1501-positive probands $(P$ uncorrected $)=0.05)$. Transmission of the A allele to HLA-DRB1*1501-negative probands was not significant $(P=0.5)$

\section{Combined analysis}

The additional genotyping data for the $-277 \mathrm{~A} / \mathrm{G}$ SNP from the familial cohort presented an opportunity to increase the number of MS patients in the case-control cohort. The data from 125 MS probands were added (Table 3). The additional data revealed that, unstratified, the TDT probands were concordant with the controls. Interestingly, stratification revealed that the TDT proband genotypes were distributed in such a way that the combined results were brought in line with the stratified control data in both subgroups. The strong LD across the region suggested that

Table 4 Haplotype frequencies for the four NOS2A promoter polymorphisms in MS patients and controls, and stratified for HLA-DRB1*1501

\begin{tabular}{|c|c|c|c|c|c|c|c|}
\hline & C-1: AGCC & C-2: GTCG & C-3: GGCG & C-4: GTTG & C-5: AGCG & C-6: GTCC & Other \\
\hline \multicolumn{8}{|l|}{ All individuals } \\
\hline MS $(n=100)$ & $123(61.5 \%)$ & $33(16.5 \%)$ & $13(6.5 \%)$ & $25(12.5 \%)$ & $3(1.5 \%)$ & 0 & $3(1.5 \%)$ \\
\hline Controls $(n=100)$ & $127(63.5 \%)$ & $30(15.0 \%)$ & $17(8.5 \%)$ & $22(11.0 \%)$ & $3(1.5 \%)$ & 0 & $1(0.5 \%)$ \\
\hline \multicolumn{8}{|l|}{ DRB1*1501 positive } \\
\hline MS $(n=60)$ & $81(67.5 \%)^{\star}$ & $17(14.2 \%)$ & $7(5.8 \%)$ & $13(10.8 \%)$ & $1(0.8 \%)$ & 0 & $1(0.8 \%)$ \\
\hline Controls $(n=29)$ & $37(63.8 \%)$ & $7(12.1 \%)$ & $8(13.8 \%)$ & $6(10.3 \%)$ & 0 & 0 & 0 \\
\hline \multicolumn{8}{|l|}{ DRB1*1501 negative } \\
\hline MS $(n=39)$ & $41(52.5 \%)^{\star}$ & $16(20.5 \%)$ & $6(7.8 \%)$ & $11(14.0 \%)$ & $2(2.6 \%)$ & 0 & $2(2.7 \%)$ \\
\hline Controls $(n=71)$ & $90(63.4 \%)$ & $23(16.2 \%)$ & $9(6.3 \%)$ & $16(11.3 \%)$ & $3(2.1 \%)$ & 0 & $1(0.7 \%)$ \\
\hline
\end{tabular}

${ }^{\star} P$ (uncorrected $)=0.04$.

All comparisons were of the AGCC haplotype versus not AGCC.

Table 5 Linkage disequilibrium between the four NOS2A SNPs

\begin{tabular}{|c|c|c|c|c|c|}
\hline Marker 1 & Marker 2 & $D^{\prime}$ & $r^{2}$ & $\chi^{2}$ & $P$ \\
\hline $\begin{array}{l}-277 \mathrm{~A} / \mathrm{G} \\
-277 \mathrm{~A} / \mathrm{G} \\
-277 \mathrm{~A} / \mathrm{G} \\
-1026 \mathrm{G} / \mathrm{T} \\
-1026 \mathrm{G} / \mathrm{T} \\
-1659 \mathrm{C} / \mathrm{T}\end{array}$ & $\begin{array}{l}-1026 \mathrm{G} / \mathrm{T} \\
-1659 \mathrm{C} / \mathrm{T} \\
-2447 \mathrm{C} / \mathrm{G} \\
-1659 \mathrm{C} / \mathrm{T} \\
-2447 \mathrm{C} / \mathrm{G} \\
-2447 \mathrm{C} / \mathrm{G}\end{array}$ & $\begin{array}{l}0.96 \\
0.92 \\
0.99 \\
1.00 \\
0.98 \\
1.00\end{array}$ & $\begin{array}{l}0.81 \\
0.47 \\
0.95 \\
0.60 \\
0.81 \\
0.49\end{array}$ & $\begin{array}{r}132.0 \\
44.3 \\
181.1 \\
72.6 \\
129.9 \\
48.6\end{array}$ & $\begin{array}{l}<0.0001 \\
<0.0001 \\
<0.0001 \\
<0.0001 \\
<0.0001 \\
<0.0001\end{array}$ \\
\hline
\end{tabular}


Table 6 Transmission disequilibrium analysis of $-277 \mathrm{~A}$ allele in all families and stratified for HLA-DRB1 *1501

\begin{tabular}{lccc}
\hline & All Individuals & HLA-DRB1 *1501-positive & HLA-DRB1 *1501-negative \\
\hline$n$ & 203 & 121 & 82 \\
Informative & 150 & 86 & 64 \\
$-277 A$ & & & 44 \\
$\quad$ Transmitted & 111 & 46 & 38 \\
$\quad$ Non-transmitted & 84 & $59 \%(50-68 \%)^{\mathrm{a}}$ & $54 \%(43-64 \%)^{\mathrm{a}}$ \\
Transmission & $57 \%(50-64 \%)^{\mathrm{a}}$ & 0.05 & 0.5 \\
$P$ (uncorrected) & 0.05 & & 54 \\
\hline
\end{tabular}

${ }^{\mathrm{a}}$ Figures in parenthesis represent $95 \%$ confidence interval.

this effect would be replicated both for the remaining three SNPs and for the haplotype analysis.

\section{Discussion}

While the HLA-DRB1*1501, DQA $1{ }^{*} 0102$, DQB1*0602 haplotype has consistently been found to associate with MS, ${ }^{4,5}$ this cannot account for all of the heritability of the disease. A number of other, non-MHC genes are each likely to make small contributions to MS susceptibility; the detection of such genes may uncover major pathways involved in pathogenesis and hence targets for drug development. In this study, we chose to analyse four SNPs in the proximal promoter region of the NOS $2 A$ gene, due to its location in a region (17q11.2) that has been shown to be of suggestive linkage and association in a number of genome wide screens, ${ }^{14-19}$ and in view of the potential for altered iNOS regulation to influence key pathogenic processes.

In our initial study of a small case-control cohort, we found a trend toward over-representation of the AGCC haplotype in HLA-DRB1*1501-positive patients, compared to negative MS patients, a finding that was not robust to the Bonferroni correction. We also established the genetic structure of the locus in our cohort.

To further explore this result, we extended the study to an analysis of transmission disequilibrium in a larger cohort of families. Our finding of a trend toward excess transmission of the -277 A allele to HLA-DRB1*1501positive probands was suggestive of an interaction between the HLA-DRB1*1501 haplotype and the NOS2A promoter in determining susceptibility to MS in HLA-DRB1*1501positive patients.

The TDT result was partially supported by the casecontrol analysis. However, the combined analysis caused the $-277 \mathrm{~A} / \mathrm{G}$ case-control results to regress towards the mean. This suggested that the initial findings in the casecontrol study may have occurred by chance, possibly as a result of the small sample size, stratification to smaller groups, or ethnic heterogeneity. A strength of transmission disequilibrium family studies is that ethnic heterogeneity is not a consideration, and thus our TDT result should be seen as more reliable.

Barcellos et $a l^{20}$ found strong evidence for linkage and association of the NOS $2 A$ locus with MS in a multilocus SNP screen. Analysis of an exon $10 \mathrm{C} / \mathrm{T}$ SNP identified significant transmission disequilibrium in HLADRB1*1501-positive families, and this was replicated in an extended data set. Extended haplotypes including the exon 10 SNP, an exon 16 SNP, and two microsatellites were also associated with MS in HLA-DRB1*1501-positive families. Genotyping data available from the website of the International HapMap Project (www.hapmap.org) revealed that the $-277 \mathrm{~A} / \mathrm{G}$ SNP is in partial LD with the exon $10 \mathrm{SNP}\left(D^{\prime}=0.88, r^{2}=0.45, \mathrm{LOD}=10.47\right)$ and the exon $16 \operatorname{SNP}\left(D^{\prime}=0.77, r^{2}=0.28\right.$, LOD $\left.=6.07\right)$. The lack of statistically significant excess transmission of the $-277 \mathrm{~A} / \mathrm{G}$ SNP to the extent found by Barcellos et $a l^{20}$ for the exon 10 SNP suggests that LD might have broken down sufficiently for the association not to be reflected at this polymorphism.

The $-277 \mathrm{~A} / \mathrm{G}$ SNP is of interest, as Hoogendoorn et al, ${ }^{40}$ in a functional study of promoter polymorphisms, found that the $-277 \mathrm{~A}$ allele conferred decreased expression in a reporter gene assay.

NOS $2 A$ is transcriptionally upregulated in response to IFN- $\gamma$ IFN- $\alpha$ and IL- $1 \beta,{ }^{9}$ and a number of transcription factors are known to bind to regulatory regions across the promoter. $^{22,24}$ Using the matrix search program on the TRANSFAC database, ${ }^{41}$ potential binding sites have been shown for the transcription factors AP4 and CP2 at the $1659 \mathrm{SNP}^{27}$ as well as a binding site for SOX5 encompassing the -1026 SNP. Burgner et al $^{27}$ have also shown altered binding of nuclear proteins in the presence of the $-1659 \mathrm{~T}$ allele in a human macrophage-like cell line. Analysis of the functional effects of these polymorphisms in the context of MS was beyond the scope of this study, but clearly is a priority for future research.

NO has been attributed both a protective and destructive role in a number of studies of EAE. Gene knockout studies 
of EAE have shown that lack of iNOS expression leads to exacerbation of disease, ${ }^{42,43}$ and a similar result was obtained by directly inhibiting iNOS. ${ }^{44}$ Increased serum levels of reactive nitrogen intermediates - indicative of iNOS activity - were also found in rats recovering from EAE. ${ }^{45}$ However, several studies have found that selective inhibition of iNOS delayed the onset of EAE and enhanced recovery, ${ }^{46,47}$ while increased iNOS levels have been found in mice with acute EAE and this correlated with severity of disease. ${ }^{48,49}$ Several studies have therefore proposed a dual role for NO, showing that iNOS activity is destructive in the acute phase of disease but protective in the progressive phase. ${ }^{50,51}$

The dual effects of NO in disease pathogenesis are well demonstrated in NOS $2 A$ knockout mice infected with Toxoplasma gondi. ${ }^{52}$ During acute infection, knockout mice survived because of the removal of an intense inflammatory response that killed most normal mice. However, the knockout mice eventually died by 30 days due to overwhelming parasitic infection, whereas surviving normal mice eventually overcame the infection.

Clearly, a fine balance exists between the destructive and immunosuppressive effects of inducible NO, such that an alteration in the level of production of $\mathrm{NO}$ - which could occur via NOS $2 A$ promoter polymorphisms - might tip this balance, with potentially dramatic consequences. In addition, NOS $2 A$ promoter polymorphisms may affect the kinetics of iNOS expression, or cellular and stimulus specificity, with corresponding differences in disease susceptibility and phenotype.

Experimental evidence suggests that NO plays some part in the pathogenesis of MS. Precisely what role it plays, however, remains unclear, especially given the great diversity of cellular sources of the molecule and its effects. The potential dual role of NO in MS pathogenesis identifies NOS $2 A$ as an important gene for which other genetic association studies might be stratified to evaluate potential epistatic interactions. While not statistically significant, our results suggest that there might be an interaction between the NOS2A promoter SNPs and HLA-DRB1*1501 in predisposing HLA-DRB1*1501-positive individuals to MS. This is the first reported investigation of potentially informative NOS $2 A$ promoter polymorphisms in MS. Further studies are necessary to determine the changes in NO expression in relation to the different phases of MS, and independent cohort studies of the NOS $2 \mathrm{~A}$ promoter polymorphisms are needed to verify our results.

\section{Acknowledgements}

We thank Najwa Marmash for technical assistance with genotyping for the family study, Susan Adams for recruitment of MS patients, Vanessa Perich, Maria Ban, Natalie Hartley and Suzy Teutsch for preparation of the DNA samples, Jenny Leary and Tracey Davis for running samples on the denaturing high-performance liquid chromatography system, Mark Wheeler and Ilya Henner for running samples for SNaPshot analysis, and Karen Byth for statistical advice. This work was supported by grants from the National Health and Medical Research Council of Australia (Grant No. 153990), and the Multiple Sclerosis Society of Australia. MB is the recipient of an Australian Postgraduate Award Scholarship and additional support was provided by Biogen Australia.

\section{References}

1 Ewing C, Bernard CC: Insights into the aetiology and pathogenesis of multiple sclerosis. Immunol Cell Biol 1998; 76: $47-54$.

2 Ebers GC, Sadovnick AD, Risch NJ: A genetic basis for familial aggregation in multiple sclerosis. Canadian Collaborative Study Group. Nature 1995; 377: 150-151.

3 Sadovnick AD, Armstrong H, Rice GP et al: A population-based study of multiple sclerosis in twins: update. Ann Neurol 1993; 33: $281-285$.

4 Compston DA, Batchelor JR, McDonald WI: B-lymphocyte alloantigens associated with multiple sclerosis. Lancet 1976; 2: $1261-1265$

5 Stewart GJ, Teutsch SM, Castle M, Heard RN, Bennetts BH: HLADR, -DQA1 and -DQB1 associations in Australian multiple sclerosis patients. Eur J Immunogenet 1997; 24: 81-92.

6 Barcellos LF, Thomson G: Genetic analysis of multiple sclerosis in europeans. J Neuroimmunol 2003; 143: 1-6.

7 Stewart GJ: Multiple sclerosis, multiple genes. Med J Australia 1997; 166: $573-574$

8 Bogdan C: Nitric oxide and the immune response. Nat Immunol 2001; 2: 907-916.

9 Nathan C: Nitric oxide as a secretory product of mammalian cells. FASEB J 1992; 6: 3051-3064.

10 Bagasra O, Michaels FH, Zheng YM et al: Activation of the inducible form of nitric oxide synthase in the brains of patients with multiple sclerosis. Proc Natl Acad Sci USA 1995; 92: 12041-12045.

11 Danilov AI, Andersson M, Bavand N, Wiklund NP, Olsson T, Brundin L: Nitric oxide metabolite determinations reveal continuous inflammation in multiple sclerosis. J Neuroimmunol 2003; 136: $112-118$.

12 Hill KE, Zollinger LV, Watt HE, Carlson NG, Rose JW: Inducible nitric oxide synthase in chronic active multiple sclerosis plaques: distribution, cellular expression and association with myelin damage. J Neuroimmunol 2004; 151: 171-179.

13 Willenborg DO, Staykova MA, Cowden WB: Our shifting understanding of the role of nitric oxide in autoimmune encephalomyelitis: a review. J Neuroimmunol 1999; 100: 21-35.

14 Giedraitis V, Modin H, Callander $M$ et al: Genome-wide TDT analysis in a localized population with a high prevalence of multiple sclerosis indicates the importance of a region on chromosome 14q. Genes Immun 2003; 4: 559-563.

15 Hensiek AE, Roxburgh R, Smilie B et al: Updated results of the United Kingdom linkage-based genome screen in multiple sclerosis. J Neuroimmunol 2003; 143: 25-30.

16 Kuokkanen S, Gschwend M, Rioux JD et al: Genomewide scan of multiple sclerosis in Finnish multiplex families. Am J Hum Genet 1997; 61: 1379-1387.

17 Sawcer S, Jones HB, Feakes R et al: A genome screen in multiple sclerosis reveals susceptibility loci on chromosome $6 \mathrm{p} 21$ and 17q22. Nat Genet 1996; 13: 464-468.

18 Sawcer S, Maranian M, Setakis E et al: A whole genome screen for linkage disequilibrium in multiple sclerosis confirms disease associations with regions previously linked to susceptibility. Brain 2002; 125: $1337-1347$.

19 Dyment DA, Sadovnick AD, Willer CJ et al: An extended genome scan in 442 Canadian multiple sclerosis-affected sibships: a report from the Canadian Collaborative Study Group. Hum Mol Genet 2004; 13: 1005-1015. 
20 Barcellos LF, Begovich AB, Reynolds RL et al: Linkage and association with the NOS2A locus on chromosome 17q11 in multiple sclerosis. Ann Neurol 2004; 55: 793-800.

21 de Vera ME, Shapiro RA, Nussler AK et al: Transcriptional regulation of human inducible nitric oxide synthase (NOS2) gene by cytokines: initial analysis of the human NOS2 promoter. Proc Natl Acad Sci USA 1996; 93: 1054-1059.

22 Marks-Konczalik J, Chu SC, Moss J: Cytokine-mediated transcriptional induction of the human inducible nitric oxide synthase gene requires both activator protein 1 and nuclear factor kappaBbinding sites. J Biol Chem 1998; 273: 22201-22208.

23 Nathan C, Xie QW: Regulation of biosynthesis of nitric oxide. J Biol Chem 1994; 269: 13725-13728.

24 Spink J, Evans T: Binding of the transcription factor interferon regulatory factor-1 to the inducible nitric-oxide synthase promoter. J Biol Chem 1997; 272: 24417-24425.

25 Morris BJ, Markus A, Glenn CL, Adams DJ, Colagiuri S, Wang L: Association of a functional inducible nitric oxide synthase promoter variant with complications in type 2 diabetes. $J \mathrm{Mol}$ Med 2002; 80: 96-104.

26 Yee LJ, Knapp S, Burgner D et al: Inducible nitric oxide synthase gene (NOS2A) haplotypes and the outcome of hepatitis $\mathrm{C}$ virus infection. Genes Immun 2004; 5: 183-187.

27 Burgner D, Usen S, Rockett $\mathrm{K}$ et al: Nucleotide and haplotypic diversity of the NOS2A promoter region and its relationship to cerebral malaria. Hum Genet 2003; 112: 379-386.

28 Burgner $\mathrm{D}, \mathrm{Xu} \mathrm{W}$, Rockett $\mathrm{K}$ et al: Inducible nitric oxide synthase polymorphism and fatal cerebral malaria. Lancet 1998; 352: $1193-1194$.

$29 \mathrm{Xu} \mathrm{W}$, Liu L, Emson P et al: The CCTTT polymorphism in the NOS2A gene is associated with dementia with Lewy bodies. Neuroreport 2000; 11: 297-299.

30 Modin H, Dai Y, Masterman T et al: No linkage or association of the nitric oxide synthase genes to multiple sclerosis. J Neuroimmunol 2001; 119: $95-100$.

31 Blanco Y, Yague J, Graus F, Saiz A: No association of inducible nitric oxide synthase gene (NOS2A) to multiple sclerosis. J Neurol 2003; 250: 598-600.

32 Burgner D, Rockett K, Ackerman $\mathrm{H}$ et al: Haplotypic relationship between SNP and microsatellite markers at the NOS2A locus in two populations. Genes Immun 2003; 4: 506-514.

33 Poser CM, Paty DW, Scheinberg L et al: New diagnostic criteria for multiple sclerosis: guidelines for research protocols. Ann Neurol 1983; 13: 227-231.

34 Kuklin A, Munson K, Gjerde D, Haefele R, Taylor P: Detection of single-nucleotide polymorphisms with the WAVE DNA fragment analysis system. Genet Test 1997; 1: 201-206.

35 Norton N, Williams NM, Williams HJ et al: Universal, robust, highly quantitative SNP allele frequency measurement in DNA pools. Hum Genet 2002; 110: 471-478.

36 Ban M, Sawcer SJ, Heard RN et al: A genome-wide screen for linkage disequilibrium in Australian HLA-DRB1*1501 positive multiple sclerosis patients. J Neuroimmunol 2003; 143: 60-64.

37 Spielman RS, McGinnis RE, Ewens WJ: Transmission test for linkage disequilibrium: the insulin gene region and insulindependent diabetes mellitus (IDDM). Am J Hum Genet 1993; 52: $506-516$
38 Becker N, Nieters A, Rittgen W: Single nucleotide polymorphism - disease relationships: statistical issues for the performance of association studies. Mutat Res 2003; 525: 11-18.

39 Johnson GC, Esposito L, Barratt BJ et al: Haplotype tagging for the identification of common disease genes. Nat Genet 2001; 29: 233-237.

40 Hoogendoorn B, Coleman SL, Guy CA et al: Functional analysis of human promoter polymorphisms. Hum Mol Genet 2003; 12: $2249-2254$

41 Wingender E, Chen X, Hehl R et al: TRANSFAC: an integrated system for gene expression regulation. Nucleic Acids Res 2000; 28: 316-319.

42 Fenyk-Melody JE, Garrison AE, Brunnert SR et al: Experimental autoimmune encephalomyelitis is exacerbated in mice lacking the NOS2 gene. J Immunol 1998; 160: 2940-2946.

43 Sahrbacher UC, Lechner F, Eugster HP, Frei K, Lassmann $\mathrm{H}$ Fontana A: Mice with an inactivation of the inducible nitric oxide synthase gene are susceptible to experimental autoimmune encephalomyelitis. Eur J Immunol 1998; 28: 1332-1338.

44 Cowden WB, Cullen FA, Staykova MA, Willenborg DO: Nitric oxide is a potential down-regulating molecule in autoimmune disease: inhibition of nitric oxide production renders PVG rats highly susceptible to EAE. I Neuroimmunol 1998; 88: 1-8.

45 O'Brien NC, Charlton B, Cowden WB, Willenborg DO: Nitric oxide plays a critical role in the recovery of Lewis rats from experimental autoimmune encephalomyelitis and the maintenance of resistance to reinduction. J Immunol 1999; 163 $6841-6847$.

46 Hooper DC, Bagasra O, Marini JC et al: Prevention of experimental allergic encephalomyelitis by targeting nitric oxide and peroxynitrite: implications for the treatment of multiple sclerosis. Proc Natl Acad Sci USA 1997; 94: 2528-2533.

47 Jolivalt CG, Howard RB, Chen LS, Mizisin AP, Lai CS: A novel nitric oxide scavenger in combination with cyclosporine $\mathrm{A}$ ameliorates experimental autoimmune encephalomyelitis progression in mice. J Neuroimmunol 2003; 138: 56-64.

48 Cross AH, Keeling RM, Goorha $\mathrm{S}$ et al: Inducible nitric oxide synthase gene expression and enzyme activity correlate with disease activity in murine experimental autoimmune encephalomyelitis. J Neuroimmunol 1996; 71: 145-153.

49 Okuda $\mathrm{Y}$, Nakatsuji $\mathrm{Y}$, Fujimura $\mathrm{H}$ et al: Expression of the inducible isoform of nitric oxide synthase in the central nervous system of mice correlates with the severity of actively induced experimental allergic encephalomyelitis. J Neuroimmunol 1995; 62: $103-112$.

50 O'Brien NC, Charlton B, Cowden WB, Willenborg DO: Inhibition of nitric oxide synthase initiates relapsing remitting experimental autoimmune encephalomyelitis in rats, yet nitric oxide appears to be essential for clinical expression of disease. J Immunol 2001; 167: $5904-5912$

51 Okuda Y, Sakoda S, Fujimura H, Yanagihara T: Aminoguanidine, a selective inhibitor of the inducible nitric oxide synthase, has different effects on experimental allergic encephalomyelitis in the induction and progression phase. J Neuroimmunol 1998; 81: 201-210.

52 Khan IA, Schwartzman JD, Matsuura T, Kasper LH: A dichotomous role for nitric oxide during acute Toxoplasma gondi infection in mice. Proc Natl Acad Sci USA 1997; 94: 13955-13960. 